\title{
Meneropong Ilmu Hukum Profetik: Penegakan Hukum yang Berketuhanan
}

\section{Ellectrananda Anugerah Ash-shidiqq}

Perkumpulan Pengacara Muda Indonesia (PERMADIN) Yogyakarta

*email: ellectra_aa@yahoo.co.id

DOI: https://doi.org/10.37729/amnesti.v2i1.701

Submitted: November 2019 Revised: Desember 2019 Accepted:Januari 2020

\begin{tabular}{|c|c|}
\hline \multirow{17}{*}{$\begin{array}{l}\text { Kata Kunci: } \\
\text { Penegakan } \\
\text { Hukum, Hukum } \\
\text { Profetik, } \\
\text { Keadilan }\end{array}$} & ABSTRAK \\
\hline & Penegakan hukum adalah suatu pekerjaan yang membutuhkan \\
\hline & keseriusan tinggi, komitmen dan semangat menegakkan keadilan \\
\hline & yang utuh namun di era pos-truth memerluakn kejelian dan \\
\hline & ketekunan dalam menjalankannya. Paradigma hukum positivistik \\
\hline & $\begin{array}{l}\text { sering mengalami kebuntuan dalam penafsiran untuk menjalankan } \\
\text { fungsi penegakan hukum. Penelitian ini bertujuan untuk }\end{array}$ \\
\hline & $\begin{array}{l}\text { menganalisis nilai-nilai profetik dalam hampir disiplin ilmu } \\
\text { menjadi suatu hal yang penting untuk dilakukan terlebih oleh }\end{array}$ \\
\hline & penegak hukum. Penegak hukum akhirnya bukanlah seorang yang \\
\hline & $\begin{array}{l}\text { sekedar digerakkan oleh pasal-pasal dalam perundang-undangan, } \\
\text { tetapi harus mengkontekstualisasi dan mengobyektifikasi nilai-nilai }\end{array}$ \\
\hline & $\begin{array}{l}\text { yang ada dalam teks terhadap fakta-fakta yang berkembang } \\
\text { sehingga keberadaan teks yang mati tersebut selaras dengan }\end{array}$ \\
\hline & $\begin{array}{l}\text { semangat konteks yang selalu dinamis, hidup dan tidak bermakna } \\
\text { tunggal. Metode penelitian yang digunakan dalam penelitian }\end{array}$ \\
\hline & $\begin{array}{l}\text { adalah penelitian kualitatif yang bersifat studi pustaka. Paradigma } \\
\text { profetik memberikan solusi bahwa persoalan krusial dalam }\end{array}$ \\
\hline & $\begin{array}{l}\text { penegakan hukum di Indonesia. Ilmu hukum profetik sebagai } \\
\text { paradigma alternatif atas pendikotomian paradigma antara basis }\end{array}$ \\
\hline & epistemogis Islam dalam ilmu hukum tersebut dengan ilmu hukum \\
\hline & itu sendiri sehingga hukum yang berkeadilan semakin mendekati \\
\hline & ( \\
\hline & ABSTRACT \\
\hline $\begin{array}{l}\text { Keywords: } \\
\text { Law } \\
\text { Enforcement, }\end{array}$ & $\begin{array}{l}\text { Law enforcement is a job that requires high seriousness, commitment and } \\
\text { enthusiasm for upholding complete justice. However, in the post-truth era, }\end{array}$ \\
\hline
\end{tabular}




Prophetic Law, it requires foresight and perseverance in carrying it out. The positivistic
Justice
legal paradigm often encounters a deadlock in interpretation to carry out
the function of law enforcement. This study analyses predictive values in
almost all scientific disciplines, which is an important thing to be done,
especially by law enforcers. Finally, law enforcers are not moved by the
provisions of laws and regulations. However, they must contextualize and
objectify the values and developmental facts contained in the text so that
dead texts are in harmony with the spirit of the context, which is always
dynamic, full of vitality, not single. The research method used in this
research is a qualitative research which is a literature study. The prophetic
paradigm provides a solution that is a crucial problem in law enforcement
in Indonesia. Prophetic law is an alternative paradigm for the paradigm
dichotomy between the epistemological basis of Islam in the science of law
and the science of law itself. A just law is getting closer to reality.

\section{PENDAHULUAN}

Manusia sebagai mahluk yang memiliki akal dan budi memiliki bermacam ragam keingintahuan mengenai hal dilaur dirinya. Dalam lintasan sejarah, rasa kengintahuan yang dalam manusia yang hadir secara kodrati menjadikan lahirnya berbagai macam ilmu dan pengetahuan yang bertujuan selain untuk memuaskan rasa ingin tahu juga untuk mempermudah manusia menjalani kehidupannya. Dr. M. J. Langeveld seorang tokoh pendidikan bangsa Belanda, memandang manusia sebagai Animal Educadum dan Animal Educable, yaitu manusia adalah makhluk yang harus dididik dan dapat dididik (Aryati, 2018).

Rasa ingin tahu manusia yang telah melalui sebuah metode dan sistem tertentu, maupun pengetahuan filsafat yang merupakan pengetahuan yang didapat melalui perenungan yang dalam dan kengintahuan sampai pada hakikatnya. Menurut Harry Haresma, filsafat itu datang sebelum dan sesudah ilmu. Harry Haresma mengatakan bahwa filsafat pada hakikatnya adala sebuah ilmu pengetahuan yang metodologis, sistematis dan saling berhubungan dengan seluruh kenyataan dan kemudian menjadi petunjuk arah kegiatan manusia dalam segala bidang kehidupannya. Salah satu contoh bukti bahwa filsafat adalah kegiatan manusia itu sendiri adalah pertanyaan yang pernah disampaikan oleh Thales bahwa alam berasal dari air, Anaximander, menyatakan bahwa alam berasal dari apa yang tidak bisa dirupakan dan Anaximendes menyatakan dan berkesimpulan bahwa alam berasal dari angin (Zulkarnaini, 2018). 
Filsafat yang dalam bahasa Inggris disebut juga "philosophy berasal dari kata philos atau filo yang berarti cinta dan sophia yang artinya kebijaksanaan, yang bila diartikan secara kontekstual adalah cinta akan kebijaksanaan. Para filsuf muslim mengatakan kata filsafat itu sendiri berasal dari bahasa Arab "falsafah". Falsafah sendiri memiliki tiga sifat pokok yakni 1) menyeluruh, 2) mendasar dan 3) spekulatif. Ketiga sifat pokok filsafat ini berarti filsafat tidak berpikir sempit tetapi melihat dari setiap sisi yang ada, berisikan pertanyaanpertanyaan diluar dari jangkauan ilmu biasa dan dalam melangkah tidak sembarangan, namun harus memiliki dasar-dasar yang dapat dipertanggung jawabkan secara ilmiah (Arif, 2014).

Di sisi lain, anak kandung dari filsafat adalah hukum. Hukum selalu berkaitan erat dengan kata adil atau keadilan. Hal tersebut sudah menjadi suatu keniscayaan (conditio sine quanon) bahwa hukum itu harus mengandung dan menjamin keadilan tatanan masyarakat. Hukum yang berkeadilan adalah hukum yang teratur dan tanpa menindas martabat kemanusiaan setiap warga masyarakat, atau dengan kata lain adalah hukum yang senantiasa mengabdi kepada kepentingan keadilan, ketertiban, keteraturan, dan kedamaian guna menunjang terwujudnya masyarakat sejahtera lahir dan batin.

Konsep-konsep hukum yang berkembang dewasa ini merupakan kelanjutan dari hukum yang didasarkan pada kekuasaan politik yang sentral . Hukum sebagai suatu profesi sangat erat dengan penegak hukum. Para penegak hukum ini adalah suatu yang sangat mulia karena mewujudkan dan menjaga ketertiban dalam masyarakat.. Posisi penegak hukum yang memiliki nilai kemuliaan tersendiri adalah suatu profesi sangat strategis karena menjadi jembatan penyelesaian resolusi konflik ketika berlangsung pertikaian, mereka juga menjadi pembela kelompok yang lemah dan dilemahkan sehingga menjadi berdaya dan setara, dan mereka juga merupakan tumpuan nasib perihal terampasnya hak-hak perseorangan dan kelompok. Karena itu, penegak hukum sesungguhnya diikat oleh etika profesi yang tidak sekedar formal tapi juga transedental.

Penegak hukum dalam sistem catur wangsa sebagaimana profesi lain diharuskan untuk tunduk pada etika profesinya, meliputi, pertama, adanya keberanian berbuat dengan tekad bertindak sesuai dengan profesinya. Kedua, menyadari terhadap profesinya. Ketiga, memiliki idealisme yang tinggi. Dalam hubungan transenden, para penegak hukum akan bertanggungjawab terhadap Tuhannya yang dalam hal ini lebih menjurus kepada suatu hal yang benar 
ataukah bertindak salah. Ikatan hubungan transeden ini merupakan suatu aktualisasi diri setiap manusia, dan merupakan nilai yang paling dasar, yaitu obyektif, positif, transenden dan intrinsik tentang tujuan hidup manusia sehingga manusia menjadi suatu mahluk yang berhubungan dengan penciptanya.

Secara kajian teoritis, berbagai macam kajian dan aliran-aliran penegakan hukum semakin berkembang. Universitas. Diponegoro terkenal dengan penegakan hukum progresifmya yang mengatakan hukum adalah bukan sekadar mengenai hukum itu semata namun tentang bagaimana manusia itu sendiri. Indonesia beruntung memiliki seorang ahli ilmu sosial yang tidak kalah dengan legenda hukum Indonesia, yang terpelajar Prof Satjipto Rahardjo.

Prof. Dr Kuntowijoyo seorang ahli ilmu sosial dalam kajiannya mengemukakan pendapat bahwa kebudayaan sebagai proses transformation in continuity and continuity in transformation. Kebudayaan tidak mungkin ada tanpa sejarah dan sejarah tidak mungkin ada tanpa kebudayaan; melalui sejarah kebudayaan terwujud, dan melalui kebudayaan sejarah tercipta. Pengertian Kebudayaan menurut Kuntowijoyo, kebudayaan adalah kompleks yang mencakup pengetahuan, kepercayaan, kesenian, moral, hukum ,adatistiadat, kemampuan-kemampuan serta kebiasaan-kebiasaan yang di dapatkan oleh manusia seagai anggota masyarakat (Ida Zahara Adibah, 2019).

Kuntowijoyo juga mengemukana teori yang saat ini di dukung oleh Universitas Muhammadiyah Surakarta sebagai pusat kajian profetiknya dengan apa yang disebut sebagai Ilmu Sosial Profetik (ISP)(Kuntowijoyo, 1991). Konsep ISP ini adalah bentuk turunan dari prinsip integrasi ilmu pengetahuan (sains) dan agama yang diyakini sepenuhnya oleh Kuntowijoyo. Secara sederhana, ilmu sosial profetik adalah ilmu sosial yang memiliki kajian transformative dan mencerahkan seperti Nabi terlepas dari agama apapun itu. Dalam tesisnya, Kuntowijoyo mengatakan intelektual profetik adalah intelektual yang akan membawa transformasi pada masyarakat bukan membawa sesuatu yang menara gading dan tak terjangkau oleh masyarakat. Tulisan singkat ini akan mengkaji bagaimana penegakan hukum melalui hukum profetik yang meminjam kajian ilmu sosial untuk menciptakan rasa keadilan yang menjadi cita dari hukum itu sendiri.

Fakta menunjukkan bahwa perkembangan iimu sosiai dan khususnya ilmu hukum, yang hendak menuju pada pemikiran paradigmatik tidak mudah 
dicapai secara akademik dan kritis. Timbuinya berbagai tantangan, baik dari pendekatan pribadi seorang/sekelompok akademikus maupun dari pendekatan kelembagaan aktor Negara/non Negara (non-stateactors). Apaiagi jika paradigma yang diusung berkarakter keagamaan (religius) tentu akan menimbulkan tantangan akademik yang serius. Pada gilirannya, justru tawaran pemikirian paradigma profetik menjadi penting dikedepankan (Thontowi, 2012).

\section{METODE PENELITIAN}

Metode penelitian yang digunakan dalam penelitian adalah penelitian kualitatif yang bersifat studi pustaka (library research) yang menggunkan bukubuku dan literatur- literatur lainnya sebagai objek yang utama. Jenis penelitian yang digunakan adalah kualitatif, yaitu penelitian yang menghasilkan informasi berupa catatan dan data deskriptif yang terdapat di dalam teks yang diteliti. Dengan penelitian kualitatif, perlu dilakukan analisis deskriptif. Metode analisis deskriptif memberikan gambaran dan keterangan yang secara jelas, objektif, sistematis, analitis dan kritis mengenai nilai-nilai penegakan hukum melalui kajian hukum profetik.

\section{HASIL DAN PEMBAHASAN}

Pengkajian terhadap nilai-nilai profetik yang dikemukakan oleh Kuntowijoyo dalam hampir disiplin ilmu menjadi suatu hal yang penting untuk dilakukan agar ilmu pengetahuan tidak terjerumus pada disiplin ilmu yang serba berbasis positivistik tanpa adanya elaborasi dan infiltrasi nilai-nilai transendental yang bersumber pada skriptual wahyu, sehingga akan mengalienasikan Tuhan sebagai pemegang otoritas tertinggi dalam aktivitas umat manusia di muka bumi ini sebagai khalifah dan mengagungkan kajian yang rasional sebagaimana terjadi pada Eropa pada abad renaisans.

Slogan tri-pilar Ilmu Sosial Profetik yang ada di kampus Universitas Muhammadiyah Surakarta menjadi modal awal untuk menggerakkan keingintahuan mahasiswa dan sebagian civitas akademika UMS agar menghidupkan kembali wacana- wacana intelektual yang mempunyai basis profetik. Dalam hal ini dimulai dengan mewacanakan kembali tri-pilar Ilmu Sosial Profetik, yaitu humanisasi, liberasi dan transendensi (Kelik Wardiono, 
2020), sebagaimana Universitas Diponegoro mengagungkan semangat Hukum progresif Prof Satjipto Rahardjo.

Humanisasi, liberasi dan transendensi menjadii tiga pilar dari ilmu sosial profetik yang digagas oleh Kuntowijoyo. Dari ketiga pilar inilah lantas akan menjadi landasan untuk mengembangkan ilmu sosial profetik dan akan menjadi ciri paradigmatisnya. Kuntowijoyo sendiri menekankan bahwa bahwa transendensi harus menjadi dasar dari dua unsur yang lain. Hal ini menunjukkan akan perhatian Kuntowijoyo terhadap signifikansi agama dalam proses theology building dalam ilmu sosial (Arum, 2018).

Jika kita melihat pada bangunan tiga pilar di atas yang dikemukakan Kuntowijoyo, mempunyai signifikansi sosial artinya bahwa aspek penekanan kepada manusia menjadi landasan dasarnya. Dalam bahasa Agama, konsep humanisasi adalah pemaknaan kreatif dari amar ma'ruf yang makna asalnya adalah penganjuran untuk menegakkan kebajikan (Husnul Muttaqin, 2015). Humanisasi berarti mempunyai makna memanusiakan manusia, menghilangkan kebendaan, ketergantungan, kekerasan, dan kebencian dari manusia. Sedangkan liberasi bermakna pembebasan. Maknanya adalah membebaskan bangsa dari kekejaman kemiskinan, keangkuhan teknologi, dan pemerasan kelimpahan. Transendensi bertujuan menambah dimensi transentral dalam kebudayaan.

Gagasan Profetik pada awalnya sebuah sintesa mayor perdebatan yang terjadi di kalangan Cendekiawan Muslim mengenai teologi yang terjadi pada sebuah seminar di Kaliurang, Yogyakarta. Terdapat dua kelompok yang tidak sepaham, yaitu kelompok yang berhaluan teologi konvensional dan kelompok yang berhaluan teologi transformatif. Kelompok tradisional mengartikan teologi sebagai ilmu kalam, yakni disiplin ilmu yang mempelajari tentang ketuhanan, yang bersifat abstrak normatif, dan skolastik. Sedangkan kelompok teologi transformatif lebih memaknai teologi sebagai penafsiran terhadap realitas dalam perspektif ketuhanan dan lebih merupakan refleksi- refleksi empiris. Kuntowijoyo, sendiri menyimpulkan perbedaan pandangan ini sulit diselesaikan karena masing-masing pihak memiliki makna dan penafsiran mengenai teologi itu sendiri sehingga kedua kubu akan sulit menemukan suatu kesimpulan. Untuk mengatasi kemacetan dialog ini Kuntowijoyo mengusulkan digantinya istilah teologi menjadi ilmu sosial, sehingga istilah Teologi Transformatif diubah menjadi Ilmu Sosial Transformatif yang dalam perkembangannya lebih dikenal dengan ilmu sosial profetik. 
Penegakan hukum di Indonesia sebagaimana sebagian besar diajarkan dalam kurikulum Sarjana di Fakultas Hukum masih berkutat di aliran filsafat rasionalisme yang beraliran positivistik. Kurikulum ini bagi sebagian orang masih dianggap sebagai hal yang normal dimana seorang sarjana hukum dituntut untuk mengerti dan menguasai secara praktis ilmu hukum itu sendiri sehingga aliran positivisme masih relatif berkembang dengan baik dengan berbagai macam variasinya.

Positivisme yang mengacu pada teori hukum murni Hans Kelsen menghendaki prosedur-prosedur metodologis dari ilmu-ilmu alam dapat langsung diterapkan dalam ilmu-ilmu sosial (Putera Astomo, 2014). Hasil penelitian hukum dapat dirumuskan dalam bentuk hukum-hukum seperti dalam ilmu-ilmu alam. Ilmu-ilmu sosial juga harus bersifat teknis sebagaimana ilmu alam yaitu menyediakan pengetahuan yang bersifat instrumental murni, netral dan bebas nilai. Ketiga pendekatan dalam paradigma positivisme ini kemudian menempatkan "hukum" dan "ilmu hukum" sebagai satu yang scientific, dan empirik. Manusia dan masyarakat dalam pembacaan ini menjadi sesuatu yang terpisah dari hukum. Padahal dalam diri hukum tidak semata hukum, tapi berkait dengan dimensi kemanusiaan dan fakt-fakta sosial yang obyektif.

Istilah hukum positif merupakan terjemahan bebas dari ius positum dari bahasa latin yang secara harfiah bermakna hukum yang ditetapkan (Christiani Widowati, 2013). Dalam dimensi tradisi paradigma positivistik itulah terbaca prilaku para penegak hukum di Indonesia yang tidak mampu bergerak emansipatoris dan progresif, tetapi sekedar menjadi alat yang instrumentalis, corong undang-undang dan pengetok palu dari teks-teks pasal yang dirumuskan dalam arena ruang kekuasaan. Hukum yang hidup di masyarakat dimarjinalisasi bahkan terhapuskan. Lebih buruk lagi, ditengah paradigma sakralisme kesucian teks-teks pasal yang logis tersebut, aparat penegak hukum di Indonesia telah biasa melangsungkan praktek jual beli pasal untuk mempertebal kantong-kantong saku mereka.

Satjipto Rahardjo mengkritik beberapa persoalan penegakan hukum di Indonesia, diantaranya, pertama, penegakan hukum yang bergerak dalam supremasi Undang-Undang dan supremasi retorika negara hukum. Padahal, sprit keadilan, kejujuran dan otentisitas penegakan hukumnya telah menipis dan menghilang. Penegakan hukum yang bergerak di jalur lambat. Proses penyelesaian hukum yang berlangsung lama, berbelit-belit dan menghabiskan 
biaya yang tidak sedikit (Faizal, 2016). Satjipto Rahardjo juga pernah mengungkapkan bahwa sistem lama, yang notabene adalah liberal itu, telah menimbulkan "penyakit-penyakit" sendiri, seperti juga telah banyak dikritik di Amerika Serikat. Di Indonesia, dalam konteks pemberantasan korupsi, sering dikatakan, bahwa pengadilan telah menjadi tempat perlindungan yang aman (safe heaven) bagi para koruptor (Swardhana, 2010).

Tradisi hukum kontinental yang semakin mendekati Anglo Saxon dalam system hukum Indonesia terklasifikasi sebagai tipe hukum pembangunan hukum yang ortodoks karena mencirikan peranan yang sangat dominan dari lembaga-lembaga negara untnuk menentukan arah hukum dalam suatu masyarakat (Abdul Hakim G. Nusantara, 1998).

Hukum bersifat positivis- instrumentalis dan menjadi alat yang ampuh bagi pelaksanaan ideologi dan program negara.Berbeda dengan paradigma responsif yang ada pada hukum adat (common law) (Amin Abdullah, 2000). Dimana ciri utamanya ialah adanya peranan besar dari lembaga-lembaga peradilan dan partisipasi yang luas bagi kelompok- kelompok sosial atau individu-individu di masyarakat dalam menentukan arah pembangunan hukum. Dalam ssitem hukum ini lembaga peradilan mempunyai peranan substansial dalam pembangunan hukum dalam system catur wangsa penegakan hukum.

Orientasi paradigma profetik dalam penegakan hukumnya sebenarnya "mirip" dengan gagasan hukum progresif yang dideklarasikan oleh Satjipto Rahardjo, dimana manusia dan rakyat merupakan tujuan dari keberadaan hukum. Penegakan hukum hukum progresif sebagaimana Suparman Marzuki katakan, ialah penegakan hukum yang submisif terhadap sistem yang ada, tetapi lebih afirmatif (affirmatif law enforcement). Afirmatif berarti keberanian untuk melakukan pembebasan dari praktek konvensional dan menegaskan penggunaaan satu cara yang lain, yang menerobos terhadap pakem-pakem praktek hukum yang telah lama berlangsung (Roger Garaudy, n.d.).

Ilmu Hukum Profetik, kiranya perlu dipikir ulang apa sebenarnya yang menjadi objek material ilmu hukum profetik itu dan bedanya dengan Ilmu Hukum pada umumnya. Untuk mengetahui hal ini, maka yang perlu dipertanyakan adalah apa sebenarnya yang menjadi hakikat dari hukum itu sendiri? Dalam Ilmu Hukum pada umumnya banyak asumsi dasar yang diikuti oleh para ilmuwan hukum untuk menjelaskan apa hakikat hukum itu(Heddy Shri Ahimsa \& Putra, 2011). Kebenaran spiritual selama ini sengaja atau tidak 
disengaja dijauhi oleh para ilmuwan, karena dianggap lekat dengan wilayah kajian teologi atau agama (Nugroho, 2016). Menurut hemat penulis tentang hal ini dapat diusulkan bahwa hakikat hukum adalah kehendak Allah yang ditujukan kepada manusia untuk mencapai derajat manusia yang mulia sebagai khalifah. Hukum berfungsi sebagai sarana dan wahana manusia untuk mendapatkan ridho-Nya. Hukum Allah harus menjadi landasan etik bagi hukum ciptaan manusia. Hukum ciptaan manusia pada dasarnya adalah perlanjutan yang konsisten dari hukum Allah. Karena itu tegak dan eksisnya hukum-hukum ciptaan manusia dapat mendatangkan malapetaka bagi manusia dengan ekosistemnya, manakala tidak bersandarkan pada kehendak Allah. Hukum yang dibuat oleh manusia harus mencerminkan misi humanisasi, leberasi dan transendensi sebagai perwujudan dari etika profetik.

\section{KESIMPULAN}

Kehadiran ilmu sosial profetik bagi kalangan akademisi merupakan penggugah etos untuk bisa melahirkan dan mengelaborasi wacana ilmu profetik terhadap disiplin ilmu pengetahuan yang lainnya,. Ilmu profetik bisa dijadikan sebagai alternatif pada saat ilmu pengetahuan saat ini terdikotomikan atau bahkan terjadi pertarungan sengit antara ilmun pengetahuan dan agama. Paradigma profetik memberikan solusi bahwa persoalan krusial dalam penegakan hukum di Indonesia ialah karena hilangnya semangat transedensi karena paradigma positivisme berkeyakinan bahwa agama dan ilmu merupakan satu yang terpisah, antara ilmu yang tidak bebas nilai dan bebas nilai. Paradigma profetik menegaskan bahwa semua ilmu dan semua profesi tidak akan bebas nilai.

\section{DAFTAR PUSTAKA}

Abdul Hakim G. Nusantara. (1998). Politik Hukum Indonesia. Yayasan Lembaga Bantuan Hukum Indonesia.

Amin Abdullah. (2000). Dinamika Islam Kultural. Mizan.

Arif, S. (2014). Filsafat Islam antara Tradisi dan Kontroversi. Jurnal TSAQAFAH, $10(1), 1-22$.

Arum, K. (2018). Pengembangan Pendidikan Agama Islam Berbasis Sosial Profetik ( Analisis Terhadap Pemikiran Kuntowijoyo ). Millah Jurnal Studi Agama, 17(2), $177-196$.

Aryati, A. (2018). Memahami Manusia Melalui Dimensi Filsafat (Upaya Memahami Eksistensi Manusia). El-Afkar, 7(2), 79-94.

Christiani Widowati. (2013). Hukum Sebagai Norma Sosial Memiliki Sifat 
Mewajibkan. ADIL : Jurnal Hukum, 4(1), 150-167.

Faizal, L. (2016). Problematika Hukum Progresif di Indonesia. Jijtimaiyya Jurnal Pengembangan Masyarakat Islam, 9(2), 1-24.

Heddy Shri Ahimsa, \& Putra. (2011). Paradigma Profetik sebuah Konsepsi. Pengembangan Ilmu Profetik 2011.

Husnul Muttaqin. (2015). Menuju Sosiologi Profetik. Sosiologi Reflektif, 10(1), 219240.

Ida Zahara Adibah. (2019). Penyelidikan Sejarah Tentang Masyarakat Dan Budaya. Jurnal Madaniyah, 9(1), 150-169.

Kelik Wardiono. (2020). Ilmu Hukum Profetik: Hampiran Basis Epistemologi Paradigmatik. UMS Press.

Kuntowijoyo. (1991). Paradigma Islam Interpretasi untuk Aksi. Mizan.

Nugroho, S. S. (2016). Pengembangan Epistemologi Ilmu Hukum Berbasis Transendental. XXI(2), 97-104.

Putera Astomo. (2014). Perbandingan Pemikiran Hans Kelsen Tentang Hukum Dengan Gagasan Satjipto Rahardjo Tentang Hukum Progresif Berbasis Teori Hukum. Yustisia, 90, 5-14.

Roger Garaudy. (n.d.). Janji-janji Islam, alih bahasa H. M. Rasjidi. Bulan Bintang.

Swardhana, G. M. (2010). Pergulatan Hukum Positivistik Menuju Paradigma Hukum Progresif. Jurnal MMH, 39(4), 378.

Thontowi, J. (2012). Paradigma Profetik Dalam Pengajaran Dan Penelitian Ilmu Hukum. XXXIV(76), 86-99.

Zulkarnaini. (2018). Analisis Perkembangan Filsafat Klasik - Modern. JIPA, II(3), 6186. 